\title{
Splinternuut deur God se genade
}

\section{Book Title:}

Wanneer God mense nuut maak: Herlewings wat nasies verander het

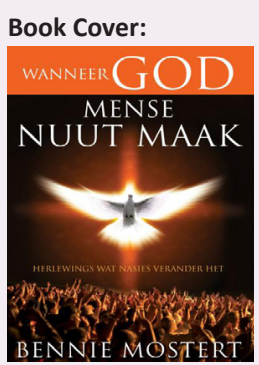

Author:

B. Mostert

ISBN:

978-7700-949-3

Publisher:

Christelike Uitgewers-

maatskappy, 2011, R69.95

*Book price at time of review

\section{-}

Review title:

Splinternuut deur God

se genade

Reviewer:

Sarah J. Wessels ${ }^{1}$

\section{Affiliation:}

${ }^{1}$ Dutch Reformed Church

Parys-East, Parys

Email:

wsjwessels@absamail.co.za

Postal address:

PO Box 2476, Parys 9585,

South Africa

How to cite this book review:

Wessels, S.J., 2013,

'Splinternuut deur God se

genade', In die Skriflig/In

Luce Verbi 47(1), Art. \#121,

1 page. http://dx.doi.org/

10.4102/ids.v47i1.121

\section{Copyright:}

C 2013. The Authors

Licensee: AOSIS

OpenJournals. This work

is licensed under the

Creative Commons

Attribution License.

\section{Read online:}

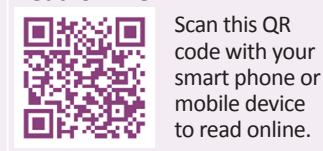

Wanneer 'n mens die webwerf van die gewilde Leserskring-boekklub besoek en op hierdie boek met die imposante voorblad klik ('n duif as teken van die Heilige Gees en 'n skare mense wat hande opsteek), wag 'n teleurstelling, want die boodskap lees: 'Jammer, geen voorraad! Hierdie item se verkope het ons verwagting oortref!' Verdere woorde is oorbodig om die gewildheid en die geslaagdheid van hierdie besondere boek te beskryf.

Bennie Mostert vertel die geskiedenis van gemeenskappe en volke wat deur kragdadige herlewings nuut gemaak is. Hy het herlewings deur die eeue nagevors en gee die verhale met buitengewone insig en passie vir die lesers weer. Meer as 40 herlewings kom aan die orde en elkeen roer diep in ' $n$ mens se gemoed. Die feite rondom sommige van hierdie herlewings is moontlik bekend, maar selde word dit so intens beleef soos wanneer Bennie Mostert dit lewendig en akkuraat oordra.

Besondere herlewings wat aandag kry, is die Vroeë Kerk in Handelinge (30-60 n.C.), die protestantse Hervorming (1500-1700), die straatherlewing in Los Angeles, VSA en herlewings in Suid-Afrika. In hierdie laaste groep kom die volgende onder die loep: die agt-dae-aardbewing van 1909, die NG Kerk en ander kerke in 1860, die Anglo-Boereoorlog in 1904, gebedsbyeenkomste gedurende 1904-1905, die Oos-Kaap in 1940-1980 en herlewings in talle van die boerekrygsgevangenekampe gedurende 1899 en 1904.

'n Gemene deler van die nagevorsde herlewings is dat dit deur ' $\mathrm{n}$ drastiese vermindering in misdaad gevolg is met geestelike waardes wat verander en vernuwe, asook genesings en wonderwerke. In die meeste gevalle is mense tot sendingwerk opgeroep gedurende sulke herlewings en langdurige sendingaksies het daarop gevolg.

In Suid-Afrika het die bekende herlewing in 1860 begin. Hierin het Andrew Murray die hoofrol gespeel en dit het landswyd alle rasse en tale ingesluit. Dit het ook die grondslag gelê vir verskeie sendingbewegings wat gevolg het en wat tot vandag toe nog 'n groot invloed op die Christendom het. Wat die leser soos 'n voorhamerhou tref, is die kardinale rol wat gebed in elkeen van die groot herlewings in die wêreldgeskiedenis gespeel het.

In Jerusalem het 120 gelowiges vir tien dae lank in die bokamer gebid na Jesus se hemelvaart voordat die Heilige Gees op hulle uitgestort is. Nader aan huis het die bekende Andrew Murray se vader 36 jaar lank vir herlewing gebid. Dit bring die lesers by die tyd waarin ons leef. Gedurende die skryf van hierdie boek (1980-2010), het miljoene Christene in elke land vir herlewing gebid en 'n mens voel gedwonge, nee geroepe deur die Heilige Gees, om ook saam te bid. Uit Bennie Mostert se navorsing leer ' $n$ mens dat gebed die sentrale beginpunt van herlewing is. Nuwe tendense van gebed is vandag moontlik, aangesien die wêreld al hoe 'kleiner' word.

Mostert sien die pad vorentoe as 'n pad van toewyding in gebed waarin elke bidder sy eie sondes bely en daarmee breek, individue wat meer tyd saam met God deurbring, en die besef dat daar geen herlewing sonder die Heilige Gees is nie. Ons taak is om die Woord te lees en terug te keer na die gesag van die Woord, te fokus op die redding van mense wat nog nie gered is nie, toe te sien dat die prediking geskied, saam met ander individue en gebedsgroepe te bid en om die evangeliese waardes na gemeenskappe buite die kerk uit te dra.

Elke Christen, sonder uitsondering, behoort hierdie boek te lees. 